\title{
Делатност Комисије за фолклористику при Међународном комитету слависта
}

\author{
Дејан Ајдачић
}

\begin{abstract}
У раду се укратко осветљавају историја Комисије за фолклористику при Међународном комитету слависта од стварања 1963. године до данас и начела делатности комисије. Указује се на активности Комисије за фолклористику у периоду од 2018. до 2021. и планиране активности до Седамнаестог конгреса слависта 2023. године, конкретно: састав комисије, билтен Slavistická folkloristika, сајт, одржане и планиране конференције, разговори о књигама, циклуси предавања, рад група и др.
\end{abstract}

Кључне речи: славистика, славистичка фолклористика, Комисија за фолклористику, Међународни конгрес слависта, конгреси слависта

Током 19. века размена академских знања о народном стваралаштву се најпре одвијала у оквиру Матица и учених друштава, а пред крај века у сусретима на свесловенским изложбама и низу новостворених часописа широм словенског света. Сарадња фолклориста се у 20. веку одвијала кроз сарадњу фолклористичких удружења, на конгресима и конференцијама слависта, фолклориста, организација Société Internationale d'Ethnologie et de Folklore (SIEF), The International Society for Folk Narrative Research (ISFNR), The International Organization of Folk Art (IOV) и др., а важно место припада и различитим видовима делатности фолклориста на конгресима у организацији Међународног комитета слависта (МКС) од првог конгреса у Прагу 1929. године до данас. 


\section{Комисија за фолклористику МКС од 1963. до 2018. године}

Комисија за студије фолклора основана је на Петом конгресу слависта у Софији 1963. године. Иницијатори за формирање Комисије били су Бугарин Петар Динеков, Пољак Јулијан Кшижановски, Чех Карел Хоралек и Рус Виктор Гусев. Први председник Комисије био је чешки фолклориста и филолог Карел Хоралек (1908-1992), који је руководио Комисијом у четири петогодишња мандата (1963-1983). Током те две деценије у Комисији је било тридесетак чланова, а најактивније су биле пољска и чехословачка секција. На Деветом конгресу слависта одржаном у Кијеву 1983. за председника је изабран совјетски фолклориста Виктор Гусев (1918-2002), који је на челу Комисије био петнаест година (1983-1998) (в.: Гусев 1994). На Дванаестом конгресу славистау Кракову руковођење Комисијом на пет година су преузели пољски фолклориста и филолог Кшиштоф Вроцлавски (р. 1937) и словачка фолклористкиња Вјера Гашпарикова (р. 1928). Када су уведени тематски блокови, ту могућност је два пута искористила Словакиња Зузана Профантова из Братиславе, која је приредила два мала зборника Slavistická folkloristika na rázcestí. XIII Medzinarodný zjazd slavistov v L'ubl'ane august 2003 (2003), Folklór a folkloristika vo svete postmoderny (2013). На Тринаестом конгресу слависта у Љубљани за председника је изабран српски фолклориста и филолог Љубинко Раденковић (р. 1951) и ту дужност је вршио у два петогодишња мандата (2003-2013). Током његовог мандата одржане су две конференције и објављени зборници радова Словенски фолклор и фолклористика на размеђи два миленијума (2008) и Заједничко у словенском фолклору (2012) (Radenković 2020). У Минску је на Петнаестом конгресу слависта председник Комисије постао руски фолклориста Андреј Мороз (р. 1970) и пет година је предводио Комисију (2013-2018). У том периоду одржане су две конференције и објављена два зборника Региональные исследования в фольклористике и этнолингвистике - проблемы и перспективы (2014, зборник 2015) и Уникальное и типичное в славянском фольклоре (2016, зборник 2019), у којима су представљени радови руских слависта фолклориста. На Шеснаестом конгресу слависта, одржаном 2018. у Београду, за председника Комисије је изабран српски фолклориста и филолог Дејан Ајдачић (р. 1959).

У Комисији за фолклористику српски чланови крајем 20. века били су Владимир Бован, Радмила Пешић, Нада Милошевић Ђорђевић, Влајко Палавестра, а из Црне Горе Вук Минић и Новак Килибарда. На досадашњих шеснаест конгреса слависта своје реферате о српском фолклору је представило тридесетак српских фолклориста, етнолога и филолога (Ајдачић 2021). 


\section{Састав Комисије за фолклористику МКС 2018-2021.}

У Извештају Андреја Мороза о активностима Комисије крајем августа 2018. године било је 115 чланова Комисије за фолклористику, од којих седам почасних. На списку су били и покојни Данац Карл Стиф (1914-1998) и Румун Николае Рошиану (1935-2012). Од 2018. године умрли су следећи чланови Комисије за фолклористику: Владимир Аникин (1924-2018), Јан Михалек (1932-2020), Зузана Профантова (1953-2018), Инес Келер Цилх (1941-2019) и Јевген Пашченко (1950-2021).

Председништво Комисије је утврдило да је део чланова неактиван и одлучило је да задржи у саставу чланове Комисије који пошаљу своју кратку биографију до краја октобра 2020. године, а да уважене колеге који су престали да учествују у академским активностима, премести у почасне чланове. Од лета 2020. до лета 2021. године, председништво је у комисију укључило 17 фолклориста: Моника Кропеј (љубљана), Евелина Рудан, Сузана Марјанић (Загреб), Смиљана Ђорђевић Белић, Немања Радуловић, Лидија Делић, Драгана Ђурић (Београд), Јеленка Пандуревић (Бања Лука), Лесја Мушкетик, Игор Јудкин (Кијев), Јарослава Конева (Олштин), Ирина Горбањ (Лавов), Галина Кабакова (Париз), Екатерина Анастасова (Софија), Јарослав Отченашек (Праг), Ивона Жепниковска (Торуњ), а чланство Антоанете Олтеану је обновљено.

Крајем маја 2021. године комисију чини 67 активних и 20 почасних чланова. У комисији су заступљени и слависти фолклористи из несловенских земаља - из Немачке (2), Израела (1), Француске (1), Канаде (1), Румуније (1), Јапана (1).

\section{Органи Комисије за фолклористику МКС}

Председништво иницира активности Комисије у петогодишњем периоду између два конгреса, одређује правце и оквире делатности Комисије између Шеснаестог и Седамнаестог конгреса слависта у Београду 2018. и Паризу 2023. године. Учешће у раду Председништва је добровољно и бесплатно, а састанци су од средине 2020. године чешћи, јер се одржавају путем видео-конференција. Председник је Дејан Ајдачић, заменици председавајућег су Виолета Врублевска и Андреј Мороз, а секретар - Мирослава Карацуба. Чланови Председништва су Татјана Валодзина (Белорусија), Лариса Вахнина (Украјина), Катарина Жењухова (Словачка), Љиљана Маркс (Хрватска), Мирјам Менцеј (Словенија), Владимир Пенчев (Бугарска), Јана Поспишилова, чије 
је место заузео Јарослав Отченашек (Чешка), Љубинко Раденковић (Србија), Љупчо Ристески (Македонија), Андреј Топорков (Русија).

\section{Slavistická folkloristika}

Билтен Slavistická folkloristika су покренули 1988. године чешки и словачки фолклористи из Брна и Братиславе, а сада га објављује Институт за етнологију Словачке академије наука као билтен Комисије за фолклористику који тренутно уређују Катарина Жењухова и Хана Хлошкова. Уреднице билтена суочавају се са проблемом недостатка чланака, јер се часопис не индексира, па стога мало људи шаље текстове. Виолета Врублевска је предложила отварање профила под називом билтен на Фејсбуку са идејом да то може подстакнути активност сарадника.

\section{Сајт Комисије за фолклористику МКС}

Концепт новог сајта Комисије http://slavika.org/folklor/ разрадио је Дејан Аидачић, који је и уредник сајта. Дизајн и развој извео је Ненад Петровић, а информативну подршку обезбедила је београдска компанија Signet. Сајт је доступан од краја маја 2020. У одељку Састав налазе се спискови чланова Комисије из 1987, 2003. и 2021. године. На збирном списку свих чланова од 1963. до 2021. године налази се 171 фолклориста, али нема многих података о години приступања Комисији због одсуства свих спискова састава Комисије. Страница Председништво садржи списак управљачког тела Комисије у периоду 2018-2023. између два конгреса. Одељак Састанци је веома важан јер нуди записнике са састанака Председништва. Посетиоци заинтересовани за историју Комисије могу да прочитају кратке информације на руском, српском и енглеском језику. У том одељку су и објављени текстови Виктора Гусева Програм активности Комисије за словенски фолклор при Међународном комитету слависта за 1989-1993, Љубинка Раденковића Rad Komisije za slovenski folklor pri MKS pod predsedništvom Ljubinka Radenkovića (2003-2013), текст Андреја Топоркова Фолклор на 14. међународном конгресу слависта (Топорков 2008), Зорана Стефановића Комисија за фолклор Међународног комитета славенски портал у 2020 (Стефановић 2020). Према списковима из зборника Oblicza slawistyki: komisje Międzynarodowego Komitetu Slawistów (1958-2013), који је уредио Станислав Гајда (Gajda 2013), као и на основу података о новооснованим комисијама 2018. године, Дејан Ајдачић је начинио 
страницу Комисије Међународног комитета слависта (1958-2018) са хронологијом формирања комисија. На основу библиографске базе радова са међународних славистичких конгреса (BibSlavKon), Ајдачић је за нови сајт Комисије приредио библиографски попис Фолклористичке публикације на Међународним конгресима слависта (Праг 1929 - Минск 2013). Из библиографске базе са немачког портала https://slavistik-portal.de, рађеног у сарадњи са Словенском библиотеком у Прагу (Slovanská knihovna), од 7767 јединица је извучено 528 библиографских описа фолклористичких радова.

Одељак Фолклористи садржи пододељке: кратке биографије активних чланова, текстове, књиге, информације о пројектима, а одељак Библиографија садржи пододељке: личне библиографије, тематске, библиографије часописа, поменута библиографија фолклористичких радова на конгресима слависта до 2013. године.

Информације о предстојећим и протеклим конференцијама се налазе у одељку Конференције. Каталог линкова упућује на веб странице фолклористичких институција, удружења, националних и међународних организација, центара, часописа. Једна веб страница садржи информације о Комисији за славистичку фолклористику на енглеском језику. Најпосећенија на сајту је страница посвећена зборнику радова Словенски фолклор и књижевна фантастика (2020), са које се може преузети и цео зборник у ПДФ формату (430 пута, 24. 5. 2021).

\section{Конференције}

Током петогодишњег периода 2018-2023, пажња Комисије за фолклористику је усмерена на проблеме терминологије наративног фолклора, везе фолклора и етнолингвистике, везе фолклора и књижевности, фолклора и визуелног приповедања, парадигме у славистичкој фолклористици. Комисија планира да буде суорганизатор неколико међународних конференција са институцијама које се баве проучавањем фолклора, а које би објавиле и одговарајући зборник радова.

Тршић 2019. Прву конференцију Комисија у новом сазиву је организовала с Удружењем фолклориста Србије, уз учешће Културних центара из Лознице и Тршића, те Универзитетске библиотеке „Светозар Марковић“ у Београду. Конференција Словенски фолклор и књижевна фантастика је одржана 27-29. септембра 2019. у завичају Вука Караџића, у Тршићу (Ајдачић 2019). Зборник који су уредили Бошко Сувајџић и Дејан Ајдачић садржи 31 рад, на бугарском, 
пољском, руском, украјинском, српском и енглеском језику. Зборник је објављен у серији „Савремена српска фолклористика“ (том 8), а радови су раздељени на три групе: 1) На рубу фолклора и књижевности, 2) Фолклор и фантастика у српској књижевности, и 3) Словенски фолклор и фантастика у словенским и несловенским књижевностима.

Кијев 2021. Институт за историју уметности, фолклористику и етнологију „Максим Рилски“ Националне академије наука Украјине, са Комисијом за фолклористику при Међународном комитету слависта, Украјинским комитетом слависта, Украјинским комитетом Међународне асоцијације за истраживање и ширење словенских култура, организује међународну научну конференцију Питања терминологије у савременом словенском фолклору 19-20. октобра 2021. На конференцији ће бити разматрани следећи проблеми: савремени приступи проучавању терминологије фолклора и фолклористике, номинација фолклорних жанрова, „народна“ и „професионална“ терминологија, семантика, прагматика, поетика фолклорног текста, фолклорна култура - етнокултурна традиција - нематеријално културно наслеђе, књижевне и фолклорне интеракције, интердисциплинарни аспекти фолклористичких студија.

Торуњ 2022. Институт за културолошке студије Универзитета „Николаја Коперника“, Комисија за фолклористику МКС и Секција за фолклористику Комитета за етнолошке науке Пољске академије наука планирају да организују Међународну научну конференцију Словенске фолклористичке парадигме 20-23. октобра 2022. године у Торуњу. На конференцији ће у средиште пажње бити постављени теоријски аспекти историје проучавања фолклора словенских народа - научне парадигме у проучавању словенског фолклора: појава фолклористичких парадигми, улога фолклориста у формирању славистичких фолклористичких парадигми, школа, односи између различитих парадигми, односи између фолклористичких парадигми и блиских дисциплина (студије религије, лингвистика фолклора, етнолингвистика, историја, археологија итд.), жанровски и наджанровски аспекти парадигми, национални аспекти, међусловенски и словенсконесловенски аспекти парадигми у словенском фолклору и фолклористици. Конференција ће се одржати у хибридном формату у Торуњу и у режиму видео-конференције на интернету.

Париз 2023. Поред низа појединачних наступа фолклориста у оквиру националних делегација на Седамнаестом конгресу у Паризу 2023. године, организатори су најавили тематски блок Дијалог научних парадигми у словенској и несловенској фолклористици 20. века (Екатерина Анастасова, Виолета Врублевска, Галина Кабакова, Александар Панченко, Немања Радуловић, Андреј Топорков, Дејан Ајдачић). 
Одлука Међународног комитета слависта о могућем укључењу фолклористичког тематског блока биће донета до краја 2021. године.

\section{Циклус Нароgна и фолклористичика имена жанрова словенскої усменої казивана}

У режиму видео-конференција одржана су три предавања посвећена сапостојању два терминолошка система, народних и научних назива у класификацији жанрова приповедног фолклора. Светлана Толстој је у предавању Лексикон фолклора: метајезик фолклора указала на етимолошке и етнолингвистичке аспекте назива врста приповедног фолклора у свим словенским језицима. Немања Радуловић је говорио о класификацији прозе у српском фолклору, а Амброз Квартич о урбаним легендама у Словенији. Циклус излагања славистафолклориста указује на међусобне везе и непоклапања назива приповедних жанрова у два дискурса, као и на особености номинације жанрова усменог приповедања у националним традицијама.

\section{О књигама}

Први састанак фолклориста слависта $O$ књигама, одржан 29. маја 2020. године, био је посвећен пољским бајкама. Тротомну књигу Słownik polskiej bajki ludowej (2018) и сајт представила је руководитељка пројекта и уредница издања Виолета Врублевска. Заинтересованост колега за овај вид разговора подстакла је Председништво да уз коришћење платформе за видео-конференције организује серију сусрета са циљем размене информација о новим књигама и часописима у словенској фолклористици. Састанци се одржавају сваког првог петка у месецу. На досадашњих шест сусрета представљени су часописи: Живая старина, Фолклористика, Български фолклор, Twórсzоść Ludowa, Literatura ludowa и двадесетак монографија и зборника. Драгоцене информације о структури и садржају књига, начину њиховог настанка праћене су и детаљима око набавке публикација. Представљене су књиге објављене у Бугарској, Пољској, Русији, Украјини, Хрватској, Србији, Босни и Херцеговини, Молдавији, Енглеској, Канади и Сједињеним Америчким Државама: Г. Скрипник (голов. ред.), Українська славістична фольклористика (XIX - початок XXI століття). Енциклопедичний словник (2019); Natalie Kononenko, Ukrainian Epic and Historical Song: Folklore in Context (2019); Folklore in the United States and Canada, ed. Patricia Sawin, Rosemary Levy Zumwalt (2020); Магические 
практики севернорусских деревень, сост. Светлана Борисовна Адонева (2020); Драгана Ђурић, Дани у недељи у народној култури Јужних и Источних Словена (2020); Јеленка Пандуревић, Фолклорни еротикон. Еротика и поетика српских народних пјесама (2020); Татьяна Григорьевна Иванова, Русские фольклористы: Биобиблиографический словарь (2020); Ljiljana Marks, Zagreb и pričama i predajama (2020); Михайло Гуць, Сербська народна пісня в Україні (2020); Kazimierz Sikora, Życzenie w gwarze i kulturze wsi (2020); Michał Luczyński, Bogowie dawnych Słowian (2020); Етнологията в променящия се свят. Сборник в чест на 80-годишния юбилей на проф. д.ф.н. Радост Иванова (2020); Фольклор украӥнців Півночі Молдови. Пісні та речитативи (2020); Jaroslav Otčenášek (ed.), České lidové pohádky I-II (2020); Jaroslav Otčenášek, Etnografický atlas Čech (2018, 2020); Marija Stanonik, Glasovi - zbirka slovenskih folklorni pripovedi (1988-2020); Сказки Евдокии Никитичны Трясциной (2020); Русские сказки Пермского края, в записях конца ХХ - начала ХХІ века (2021); Иван Степанович Јастребов, Обичаји и песме Срба у Турској (2021); Етнология и епидемии. Социокултурни измерения на пандемиятаот COVID-19. Съст. Вихра Баева и Ангелина Илиева (2021); Saša Babič, Uganke na Slovenskem (2021); Надія Ковальчук, Традиційні свята та обряди Рівненького Полісся: структура, термінологія, географія поширення (середина XX $\mathrm{cm})$.

\section{Групе у оквиру Комисије за фолклористику МКС}

Комисија је предложила нови вид сарадње фолклориста у оквиру група, ако иницијатор групе обезбеди учешће фолклориста из најмање три земље. Група може да представља своје идеје и циљеве на веб страници Комисије. Рад групе може да се тиче проблема теорије и историје фолклористике, израде библиографија итд. Председништво комисије је 21. маја 2021. године подржало формирање радне групе Фигуративно (визуелно) приповедање словенског фолклора на предлог Зорана Стефановића (Београд). Према предложеном програму, група ће истраживати фолклор у визуелној литератури и комуникацији и то: системе знакова и симбола; приповести и циклусе на фрескама и иконама; народне графике, везове, дуборезе итд.; стрип и графичке новеле; сликовнице; књижну илустрацију; карикатуру; визуелни интерфејс; концептуалну уметност (concept art) и визуелне књиге снимања (storyboard) за филмове, анимацију, видео-игре и виртуелне светове итд.

Комисија за фолклористику је (у време пандемије вируса Covid-19) искористила могућности видео-комуникације и интензивирала своје 
активности. Проширене могућности сарадње на даљину ће се и даље остваривати у оквирима разговора о новим издањима, предавањима, рада група при Комисији за фолклористику. Шездесетогодишњица деловања комисије биће прослављена и у Паризу. Планиране и најављене активности требало би да осветле и део историје делатности комисије у токовима славистичке фолклористике.

\section{Библиографија}

Ајдачић, Д. (2021). Радови о српском фолклору на Међународним конгресима слависта (1929-2018), прилог историји фолклористике (рад представљен на научном скупу Савремена српска фолклористика 9, 2-4. 10. 2020. Тршић, Србија) - у штампи.

Ајдачић, Д. (2019). О међународној конференцији „Словенски фолклор и књижевна фантастика“у Тршићу (2019). Славистика, 2(23), 266-267.

Гусев, В. (1994). Программа деятельности Комиссии по славянскому фольклору при Международном комитете славистов на 1989-1993 гг. Живая старина, 1, 63.

Стефановић, 3. (2020). Комисија за фолклористику Међународног комитета слависта у 2020: нови интернет портал као нови увид у светску славистику. Славистика, 2(24), 522-525. http://slavika.org/folklor/komissiya/ istoriya/268-stefanovic-portal (24. 05. 2021).

Топорков, А. (2008). Фольклористика на XIV Международном съезде славистов (2008). http://slavika.org/folklor/komissiya/istoriya/209-toporkov-14sjezd (24. 05. 2021)

BibSlavKon. Bibliographie der internationalen Slavistenkongresse https://slavistikportal.de/datenpool/bibslavkon-db.html (24.05. 2021).

Gajda, S. (red.). (2013). Oblicza slawistyki: komisje Międzynarodowego Komitetu Slawistów (1958-2013). Opole: Wydawnictwo Uniwersytet Opolski.

Žeňuch, P. (2019). Komisie pri Medzinárodnom komitéte slavistov akreditované na 16. medzinárodnom zjazde slavistov v Belehrade. Slavia, 88, 1, 100-104.

Radenković, Lj. (2020). Rad Komisije za slovenski folklor pri MKS pod predsedništvom Ljubinka Radenkovića (2003-2013). http://slavika.org/folklor/komissiya/ istoriya/207-komisija-2003-20 (24.05. 2021) 


\title{
Activity of The Commission on Folklore of The International Committee of Slavists
}

\section{Dejan Ajdačić}

\begin{abstract}
Summary
Commission on Folklore was founded in 1963 within the International Committee of Slavists, and this paper presents a concise survey of its history and its basic principles. In focus are the actions of the Commission on Folklore in period from 2018 to 2021, as well as activities planned for the 17th Congress of Slavists in 2023 - namely: members of the commission, its bulletin Slavistická folkloristika, website, held and planned conferences, discussions on books, lecture series, group activities, etc.
\end{abstract}

Keywords: Slavistics, Slavic folklore studies, Commission on Folklore, International Committee of Slavists, congress of Slavists

проф. др Дејан Ајдачић

Wydział Filologiczny, Uniwersytet Gdański

Примљено: 25. 5. 2021.

Е-пошта: dejan.ajdacic@ug.edu.pl

Прихваћено: 10.6. 2021. 